\title{
Perbedaan Kadar IL- 0 pada Preeklampsia Tipe Dini dan Lambat
}

\author{
Ario Danianto, Ernawati \\ Departemen Obstetri Ginekologi, Fakultas Kedokteran Universitas Airlangga, RSUD dr. Soetomo, Surabaya
}

\section{ABSTRAK}

Tujuan: Menganalisis perbedaan kadar IL-10 antara preeklampsia tipe dini dan preeklampsia tipe lambat.

Bahan dan Metode: Penelitian ini melibatkan 56 wanita hamil yang terbagi menjadi empat kelompok, yaitu wanita hamil normal usia kehamilan 30-34 minggu, wanita hamil normal usia > 34 minggu, preeklampsia berat tipe dini (30-34 minggu), preeklampsia berat tipe lambat (> 34minggu). Pemeriksaan IL-10 dilakukan saat penderita masuk rumah sakit dan didiagnosis sebagai preeklampsia dengan menggunakan metode ELISA

Hasil: Rerata kadar IL-10 pada kelompok preeklampsia tipe dini $(0,37 \pm 0,14)$ lebih rendah dibandingkan kelompok preeklampsia tipe lambat $(0,87 \pm 0,43)$ dengan $\mathrm{P}<0,001$. Rerata kadar IL-10 pada kelompok preeklampsia tipe dini $(0,37 \pm 0,14)$ lebih rendah dibandingkan kelompok wanita hamil normal usia 30 -34 minggu $(0,84 \pm 0,42)$ dengan $\mathrm{P}<0,001$. Tidak didapatkan perbedaan rerata kadar IL-10 pada kelompok preeklampsia tipe lambat $(0,87 \pm$ $0,43)$ dibandingkan kelompok wanita hamil normal usia > 34minggu $(0,75 \pm 0,68) \mathrm{P}=0,22$.

Simpulan: Keadaan inflamasi berat terjadi pada preeklampsia berat tipe dini

Kata Kunci : preeklampsia tipe dini, preeklampsia tipe lambat, IL-10

\begin{abstract}
Objectives: To analyze the difference of IL-10 concentration in early and late onset of preeclampsia.

Materials and Methods: Cross-sectional analytic study was conducted on 56 pregnant women, divided into four groups : one groups of normal pregnant women with $>30-34$ weeks of gestation, one group of normal pregnant women with $>34$ weeks of gestation, one group of early onset preeclampsia (30-34 weeks), one group of late onset of preeclampsia (>34 weeks). Plasma IL-10 concentration examination was collected patient admitted in hospital and diagnosed preeclampsia. Plasma IL-10 was determined by ELISA.

Results: Mean plasma IL-10 concentration on early onset preeclampsia group $(0,37 \pm 0,14)$ was lower than late onset preeclampsia group $(0,87 \pm 0,43),(\mathrm{p}<0,001)$. Mean plasma IL-10 concentration on early onset preeclampsia group $(0,37 \pm 0,14)$ was lower than normal pregnant women with $>30-34$ weeks of gestation $(0,84 \pm 0,42), \quad(\mathrm{p}<0,001)$. Median plasma IL-10 concentration on late onset preeclampsia group $(0,87 \pm 0,43)$ was higher than normal pregnant women with $>34$ weeks of gestation $(0,75 \pm 0,68)$, but not statistically significant $(\mathrm{p}=0,22)$.

Conclusion: Severe inflammation happened in early onset preeclampsia.
\end{abstract}

Keywords: preeclampsia, late onset, early onset, IL-10

Correspondence: Ario Danianto, Departemen/SMF Obstetri Ginekologi, Fakultas Kedokteran Universitas Airlangga - RSUD dr. Soetomo, Surabaya, Jawa Timur, Indonesia, Telp: +6287852000306, email: Nyok_306ad@yahoo.com

\section{PENDAHULUAN}

Preeklampsia merupakan masalah obstetri utama diseluruh dunia terutama negara berkembang yang dapat menyebabkan morbiditas dan mortalitas pada ibu dan janinyang mempengaruhi $2-10 \%$ kehamilan diseluruh dunia. Lebih dari 4 juta wanita hamil tiap tahunnya terjadi preeklampsia dan menyebabkan $15-20 \%$ kematian wanita hamil diseluruh dunia. ${ }^{1}$

Hipotesis tentang preeklampsia saat ini adalah berfokus pada maladaptasi respon imun dan kegagalan invasi trofoblas. Peningkatan respon inflamasi yang berlebih dari maternal sebagai respon terhadap antigen asing dari janin dapat menimbulkan rangkaian peristiwa berupa invasi trofoblast yang tidak memadai, kegagalan remodeling arteri spiralis, iskemia plasenta dan pelepasan sitokin pro inflamasi dan fragment plasenta dalam sirkulasi sistemik. $^{2}$

Salah satu mekanisme yang terlibat dalam mekanisme preeklampsia adalah respon inflamasi sistemik yang berlebihan akibat dekomposisi dari satu atau lebih dari sistem imun maternal. Selama kehamilan terjadi peningkatan respon imun terhadap inflamasi. Pada preeklampsia telah terbukti memiliki kadar produk Th1 (pro-inflamasi) yang lebih tinggi dan kadar produk Th2 (anti-inflamasi) yang lebih rendah dibandingkan dengan kehamilan normal pada serum darah. ${ }^{3}$

T-helper memiliki peran penting dalam mengatur sel imun dengan produksi sitokin tertentu. Th1 memproduksi sitokin inflamasi, yaitu Tumor Necrosis Factor (TNF)- $\alpha$, Interferon (IFN)- $\gamma$ dan IL2. Sedangkan Th2 memproduksi sitokin anti inflamasi, yaitu IL-4, IL-5, IL-9, IL-10 dan IL-13. Kehamilan normal selalu dihubungkan dengan kondisi imun Th2 yang memberikan lingkungan imunotoleransi untuk menghindari rejeksi janin. Sedangkan pada preeklampsia ditandai dengan dominasi Th1 dimana terjadi peningkatan sitokin proinflamasi. ${ }^{4}$

Peran sitokin interleukin-10 (IL-10) telah banyak diteliti pada proses infeksi dan inflamasi yang terjadi pada wanita tidak hamil, karena kemampuan pentingnya sebagai imunosupresan dalam merespon berbagai 
keadaan inflamasi. IL-10 merupakan sitokin yang memiliki peran penting pada kehamilan yaitu mengatur respon imun maternal, memiliki efek anti-inflamasi, dan efek pada vaskuler di maternal-fetal interface. Selama kehamilan, kadar IL-10 meningkat pada awal kehamilan dan terus meningkat sampai trimester ketiga kehamilan. Peran IL-10 selama kehamilan adalah menekan imunitas maternal untuk memungkinkan penerimaan sifat allograft janin. Selain itu sekresi IL-10 oleh beragam sel maternal dan janin terbukti berperan dapat menjaga proses kehamilan yang normal. ${ }^{5}$

Kehamilan normal dapat membangkitkan inflamasi ringan. Respon yang terjadi dari setiap wanita dapat bervariasi dan melibatkan leukosit, aktivasi endotel, respon fase akut dan proses metabolik. Beberapa respon dapat dianggap sebagai adaptasi fisiologis dari kehamilan. Seiring dengan bertambahnya usia kehamil-an, respon inflamasi menjadi lebih kuat dan mencapai puncaknya pada trimester ketiga kehamilan. Perubahan ini berkaitan dengan peningkatan sitokin inflamasi di sirkulasi pada trimester kedua kehamilan. ${ }^{6}$

Dalam beberapa tahun terakhir, lahir konsep terbaru tentang usia kehamilan saat munculnya klinis preeklampsia. Diklasifikasikan berdasar waktu terjadinya onset penyakit : tipe dini (early onset) preeklampsia yang terjadi sebelum atau saat usia kehamilan 34 minggu dan tipe lambat (late onset) preeklampsia yang terjadi pada usia kehamilan 34 minggu atau lebih. ${ }^{7}$ Konsep tipe dini dan tipe lambat telah diterima secara luas bahwa hal tersebut merupakan dua bentuk preeklampsia yang mempunyai etiologi yang berbeda.

Plasentasi yang abnormal dilaporkan sebagai patofisiologi utama dalam mekanisme preeklampsia tipe dini, sedangkan predisposisi risiko kardiovaskuler atau metabolik yang menyebabkan kerusakan endotel dan respon inflamasi yang berlebihan tampaknya lebih berperan dalam patofisiologi preeklampsia tipe lambat. Perbedaan ini telah didukung oleh analisis temuan patologis pada plasenta dan faktor-faktor yang beredar dalam sirkulasi maternal. $^{8}$

Berdasarkan adanya perbedaan patofisiologi yang mendasari terjadinya preeklampsia berat tipe dini dan lambat yang kemudian akan mempengaruhi luaran maternal dan perinatal maka kami melakukan penelitian untuk melihat kondisi sitokin anti-inflamasi pada penderita preeklampsia berat tipe dini dan tipe lambat yang kami bandingkan dengan kehamilan normal. Pada penelitian ini kami memeriksakan kadar IL-10 serum pada penderita preeklampsia berat tipe dini, tipe lambat dan kehamilan normal sebagai kelompok kontrol

\section{BAHAN DAN METODE}

Subjek pada penelitian ini sebanyak 56 orang, dengan rincian kelompok preeklampsia berat tipe dini (usia kehamilan 30-34) 15 orang, kelompok preeklampsia berat tipe lambat (usia kehamilan > 34 minggu) 15 orang, kelompok hamil normal usia kehamilan 30-34 minggu 13 orang, kelompok hamil normal usia kehamilan $>34$ minggu 13 orang. Penelitian ini dilakukan di RSUD Dr. Soetomo Surabaya dan RSU Soewandhie mulai bulan Juni 2013 sampai dengan Februari 2015. Pengambilan serum darah pada wanita hamildengan preeklampsia dilakukan saat subyek pertama kali didiagnosis sebagai preeklampsia. Preeklampsia berat didefinisikan sebagai adanya Tekanan darah sistolik $\geq 160 \mathrm{mmHg}$ dan tekanan darah diastolik $\geq 110 \mathrm{mmHg}$, Proteinuria lebih $5 \mathrm{~g} / 24$ jam atau $4+$ dalam pemeriksaan kualitatif.

Pemeriksaan IL-10 menggunakan metode ELISA quantikine high sensitivity human IL-10 immonoassay. Penelitian ini dilakukan secara cross sectional. Analisis dilakukan menggunakan bantuan software SPSS 20. Dilakukan uji komparasi dengan independent $\mathrm{T}$ test dan Mann-Whitney sesuai dengan distribusi data variabel IL-10 pada masing-masing kelompok. Probabilitas dianggap bermakna secara statistik apabila didapatkan nilai $\mathrm{p}<0,05$.

\section{HASIL DAN PEMBAHASAN}

\section{Karakteristik Subjek Penelitian}

Dari kedua kelompok preeklampsia berat kami membandingkan beberapa karakteristik yang merupakan faktor resiko terjadinya preeklampsia. usia, paritas dan indeks massa tubuh merupakan beberapa faktor risiko terjadinya preeklampsia.

Tabel 1. Karakteristik Subjek Penelitian

\begin{tabular}{cccc}
\hline Kriteria & $\begin{array}{c}\text { Tipe Dini } \\
(\mathrm{n}=15)\end{array}$ & $\begin{array}{c}\text { Tipe Lambat } \\
(\mathrm{n}=15)\end{array}$ & $\mathrm{p}$ \\
\hline Usia (tahun) & $33,13 \pm 5,91$ & $33,86 \pm 5,52$ & 0,728 \\
Paritas & & & \\
Primi & $6,66 \%$ & $33,33 \%$ & \\
Multi & $93,33 \%$ & $66,67 \%$ & \\
IMT $\left(\mathrm{kg} / \mathrm{m}^{2}\right)$ & $24,00 \pm 3,21$ & $24,96 \pm 4,09$ & 0,475 \\
\hline
\end{tabular}

*signifikan bila nilai $\mathrm{p}<0,05$

Pada penelitian ini didapatkan rata-rata kadar IL-10 serum pada kelompok preeklampsia berat tipe dini lebih rendah dibandingkan kelompok hamil normal usia kehamilan 30-34 minggu $(0,37 \pm 0,14$ vs $0,84 \pm 0,42)$. 
Dari uji T didapatkan perbedaan bermakna kadar IL-10 serum pada kedua kelompok tersebut $(\mathrm{p}<0,001)$.

Tabel 2. Perbandingan kadar IL-10 pada preeklampsia berat tipe dini dan kontrol (hamil normal usia kehamilan 30-34 minggu)

\begin{tabular}{cccc}
\hline Kriteria & $\begin{array}{c}\text { Preeklampsia } \\
\text { Berat Tipe Dini }\end{array}$ & Kontrol & $\mathrm{p}$ \\
\hline $\mathrm{IL}-10 \mathrm{pg} / \mathrm{mL}$ & $0,37 \pm 0,14$ & $0,84 \pm 0,42$ & 0,001 \\
\hline
\end{tabular}

*signifikan bila nilai $\mathrm{p}<0,05$

Pada penelitian ini kami dapatkan rata-rata kadar IL-10 serum pada kelompok preeklampsia berat tipe lambat lebih rendah dibandingkan kelompok kontrol (hamil normal usia kehamilan $>34$ minggu $)(0,87 \pm 0,43$ vs 0,75 $\pm 0,68$ ). Dari uji T tidak didapatkan perbedaan bermakna kadar IL-10 serum pada kedua kelompok tersebut $(\mathrm{p}=0,22)$.

Tabel 3. Perbandingan kadar IL-10 pada preeklampsia berat tipe lambat dan kontrol (hamil normal usia kehamilan >34 minggu)

\begin{tabular}{cccc}
\hline Kriteria & $\begin{array}{c}\text { Preeklampsia Berat } \\
\text { Tipe lambat }\end{array}$ & Kontrol & $\mathrm{p}$ \\
\hline $\mathrm{L}-10 \mathrm{pg} / \mathrm{mL}$ & $0,87 \pm 0,43$ & $0,75 \pm 0,68$ & 0,22 \\
\hline
\end{tabular}

*signifikan bila nilai $\mathrm{p}<0,05$

Pada penelitian ini didapatkan kadar IL-10 serum pada kelompok preeklampsia berat tipe dini lebih rendah dibandingkan kelompok tipe lambat ( $0,37 \pm 0,146$ vs $0,87 \pm 0,43)$. Dari uji T didapatkan perbedaan bermakna kadar IL-10 pada preeklampsia tipe dini dan tipe lambat $(\mathrm{p}<0,001)$.

Tabel 4. Perbandingan kadar IL-10 pada preeklampsia berat tipe dini dan lambat

\begin{tabular}{cccc}
\hline Kriteria & Tipe Dini & Tipe Lambat & p \\
\hline IL-10 pg/mL & $0,37 \pm 0,14$ & $0,87 \pm 043$ & $\begin{array}{c}< \\
\end{array}$ \\
\hline
\end{tabular}

*signifikan bila nilai $\mathrm{p}<0,05$

Manifestasi preeklampsia dapat berkembang pada usia kehamilan sebelum, pada saat 34 minggu (tipe dini), lebih 34 minggu (tipe lambat), selama persalinan, maupun postpartum. Preeklampsia tipe dini berkaitan dengan pertumbuhan janin terhambat dan adanya lesi iskemik pada plasenta. Sedangkan preeklampsia tipe lambat tidak berkaitan dengan pertumbuhan janin terhambat maupun lesi iskemik pada plasenta. Saat ini preeklampsia tipe dini dan tipe lambat dianggap memiliki patofisiologi yang berbeda. Hal ini didukung oleh pengamatan adanya perbedaan dalam hal fungsi neutrophil dan kadar sitokin pada tipe dini maupun tipe lambat. ${ }^{9,10}$

Berdasarkan adanya perbedaan patofisiologi yang mendasari terjadinya preeklampsia berat tipe dini dan lambat yang kemudian akan mempengaruhi luaran maternal dan perinatal maka kami melakukan penelitian untuk melihat kondisi sitokin anti-inflamasi pada penderita preeklampsia berat tipe dini dan tipe lambat yang kami bandingkan dengan kehamilan normal

Secara umum didapatkan rerata usia pada kelompok preeklampsia tipe lambat lebih tua dibandingkan tipe dini $(33,86$ vs $33,13, p=0,278)$. Meskipun usia merupakan faktor resiko terjadinya preeklampsia, tetapi belum jelas bagaimana pengaruh usia pada preeklamp-sia tipe dini maupun lambat. Mekanisme dibalik resiko ini mungkin terkait dengan terjadinya penuaan pembuluh darah uterus. ${ }^{11}$

Secara keseluruhan pada kelompok preeklampsia dominan terjadi pada multigravida. Hal ini agak berbeda dengan hasil dibeberapa literatur yang menunjukan bahwa preeklampsia merupakan penyakit pada kehamilan pertama. Adanya beberapa faktor tambahan, seperti faktor suami, riwayat kehamilan sebelumnya, interval kehamilan pada subjek penelitian ini dapat meningkatkan resiko terjadinya preeklampsia pada multiparitas, sehingga data ini hanya menunjukkan distribusi paritas pada kelompok preeklampsia berat pada penelitian ini. Pada kelompok multigravida kami dapatkan 13,3\% merupakan kehamilan dengan suami yang berbeda dan 26,6\% adalah kehamilan dengan interval kehamilan lebih dari sepuluh tahun.

Pada penelitian ini Ada kecenderungan bahwa pada kelompok preeklampsia tipe lambat mempunyai nilai rata-rata indeks massa tubuh yang lebih tinggi dibandingkan dengan tipe dini. Beberapa studi dengan populasi yang besar telah menunjukkan bahwa wanita obesitas mempunyai resiko dua sampai tiga kali untuk terjadi preeklampsia dibandingkan dengan wanita yang tidak obesitas. ${ }^{12}$ Jaringan adipose putih dianggap hanya sebagai tempat penyimpanan lipid. Sebaliknya adipose merupakan organ endokrin yang sangat aktif dan terlibat dalam keseimbangan nutrisi, respon imun, kontrol tekanan darah, tiroid dan fungsi reproduksi. Sel adipose memproduksi dan melepaskan banyak zat aktif biologis seperti leptin, adiponektin, IL-1, IL-6, IL-8, IL-10, TNF- $\alpha$, Interferon- $\gamma$, monocyte chemoattaractant protein (MCP)-1 yang secara kolektif disebut adipokines. Leptin dan adiponektin secara khusus diproduksi oleh jaringan adipose putih yang memiliki efek saling berlawanan. Adiponektin dianggap sebagai faktor dengan sifat anti-inflamasi yang kadarnya berkurang pada obesitas, sementara leptin merupakan mediator 
pro-inflamasi yang kadarnya bertambah pada obesitas. Studi invitro pada sel endotel yang dikultur menunjukkan peran leptin dalam adhesi dan per-pindahan dari makrofag, sehingga ikut bertanggung jawab terhadap infiltrasi makrofag. Infiltrasi makrofag kedalam struktur disekitar adipositit akan memicu parakrin untuk melakukan interaksi dengan sel adipose yang pada akhirnya interaksi ini akan memperburuk perubahan inflamasi dijaringan adipose dan selanjutnya akan berkontribusi pada pelepasan sitokin pro-inflamasi dalam sirkulasi. ${ }^{13}$

\section{Interleukin- I 0 pada Kehamilan Normal}

Kehamilan dapat dipisahkan menjadi tiga periode imunologi yang berbeda: saat implantasi merupakan keadaan inflamasi, selama kehamilan merupakan keadaan anti-inflamasi dan pada saat proses persalinan merupakan keadaan inflamasi. Menjaga keadaan imunitas sesuai dengan periodenya sangat penting untuk menghasilkan luaran kehamilan yang baik. Ekspresi IL10 pada jaringan plasenta manusia menunjukkan kadar yang lebih tinggi pada trimester pertama dan kedua kehamilan dibandingkan trimester ketiga, hal ini menunjukkan peran imunosupresif dari IL-10 selama kehamilan. ${ }^{14}$

Analisis imunohistokimia dan pemeriksaan ELISA dari jaringan plasenta yang diambil dari kehamilan normal, menunjukkan bahwa jumlah produksi IL-10 tergantung dengan usia kehamilan. Kadar IL-10 pada trimester pertama dan kedua di jaringan plasenta signifikan lebih tinggi daripada yang ditemukan pada trimester ketiga. Hal ini memberi kesan bahwa secara intrinsik terjadi downregulation pada saat kehamilan aterm untuk menyiapkan persalinan yang diprogram oleh suasana inflamasi. $^{15}$

Pada penelitian ini kami membandingkan kadar IL-10 serum pada preeklampsia berat tipe dini dengan hamil normal usia kehamilan 30-34 minggu sebagai kontrol. Nilai rata-rata kadar IL-10 pada kelompok preeklampsia berat tipe dini $0,37 \mathrm{pg} / \mathrm{mL}$ dan kelompok kontrol 0,84 $\mathrm{pg} / \mathrm{mL}$. Dari uji T kami dapatkan perbedaan bermakna pada kedua kelompok tersebut $(\mathrm{P}<0,001)$. Rata-rata kadar IL-10 lebih rendah secara bermakna pada kelompok preeklampsia berat tipe dini dibandingkan dengan kontrol pada penelitian ini menunjukkan adanya kondisi inflamasi berat disebabkan maternal underperfusion sehingga terjadi hipoksia/iskemia plasenta dan terjadi penurunan kadar sitokin anti-inflamasi.

Pada penelitian ini kami juga membandingkan kadar IL10 serum pada preeklampsia berat tipe lambat dengan hamil normal usia kehamilan > 34 minggu sebagai kontrol. Nilai rata-rata kadar IL-10 serum pada kelompok preeklampsia berat tipe lambat $0,87 \mathrm{pg} / \mathrm{mL}$ dan kelompok kontrol $0,75 \mathrm{pg} / \mathrm{mL}$. Dari uji $\mathrm{T}$ tidak kami dapatkan perbedaan bermakna pada kedua kelompok tersebut $(\mathrm{p}=0,22)$.Didapatkan rata-rata kadar IL10 serum lebih tinggi pada kelompok preeklampsia berat tipe lambat dibandingkan dengan kontrol. Pada akhir kehamilan terjadi peningkatan respon inflamasi sehingga kadar sitokin anti-inflamasi termasuk IL-10 akan menurun. Fisiologis peningkatan respon inflamasi maternal pada akhir kehamilan belum jelas, mungkin terkait dalam persiapan persalinan. Peningkatan sitokin pro-inflamasi juga diperlukan untuk merangsang produksi MMP-1, MMP-3, MMP-9 yang diperlukan untuk pematangan servik. ${ }^{16}$

Pada akhir kehamilan normal juga terjadi peningkatan respon inflamasi yang berperan untuk persiapan persalian begitu juga yang terjadi pada preeklampsia tipe lambat. Pada wanita yang memiliki maternal konstitusi terjadi peningkatan ambang batas inflamasi, sehingga dengan adanya inflamasi kronik dengan intensitas rendah dapat menyebabkan timbulnya gejala preeklampsia.

\section{Interleukin-10 pada Preeklampsia}

Preeklampsia merupakan gangguan sistemik yang disebabkan oleh proses plasentasi yang buruk. Meskipun patogenesis preeklampsia masih kurang dipahami, invasi trofoblas yang kurang memadai dan remodeling arteri spiralis yang buruk mengakibatkan hipoksia dan iskemia pada plasenta yang merupakan kejadian praklinis utama yang terjadi pada maternal-fetal interface. Sehingga plasenta akan mengeluarkan molekul inflamasi dan faktor anti-angiogenik yang tampak pada sirkulasi sistemik maternal yang kemudian mengakibatkan disfungsi endotel dan gejala hipertensi, proteinuria dan kerusakan ginjal. Produksi IL-10 yang berkurang dapat menyebabkan plasentasi yang buruk dan induksi faktor-faktor anti-angiogenik vasoaktif. Hal tersebut sesuai dari evaluasi jaringan dan serum plasenta dari sampel preeklampsia didapatkan pengurangan kadar IL-10. ${ }^{14}$

Dari bukti epidemiologi, uji klinis dan studi biologis cukup kuat mendukung pandangan bahwa preeklampsia mempunyai asal usul dan fenotif yang berbeda. Asal pertama adalah berawal dari plasenta yang biasanya terjadi pada awal kehamilan dan berhubungan dengan plasentasi yang buruk serta berbagai macam derajat keparahan pertumbuhan janin yang terhambat. Hal ini tampaknya sesuai dengan patofisiologi utama pada mekanisme preeklampsia tipe dini. Asal kedua adalah maternogenik yang pada umumnya terjadi pada akhir kehamilan dan tidak berhubungan dengan insufisiensi plasenta dan gangguan pertumbuhan janin. Kondisi ini 
terkait dengan inflamasi kronis dengan intensitas rendah seperti kenaikan indeks massa tubuh dan resistensi insulin. Disfungsi endotel merupakan jalur akhir yang umum dari dua postulat tersebut. ${ }^{13}$

Pada penelitian ini kami ingin menilai peran IL-10 sebagai sitokin yang memiliki peran penting dalam keseimbangan inflamasi dan anti-inflamasi pada preeklampsia. Hasil pada penelitian ini didapatkan nilai rata-rata kadar IL-10 serum pada kelompok preeklampsia berat tipe dini $0,37 \mathrm{pg} / \mathrm{mL}$ dan tipe lambat $0,87 \mathrm{pg} / \mathrm{mL}$. Dari uji T kami dapatkan perbedaan bermakna pada kedua kelompok tersebut $(\mathrm{p}<0,001)$. Didapatkan rata-rata kadar IL-10 lebih rendah pada kelompok preeklampsia berat tipe dini dibandingkan dengan tipe lambat. Hal ini menunjukkan keadaan inflamasi yang lebih berat pada preeklampsia berat tipe dini dibandingkan tipe lambat sehingga dapat diasumsikan bahwa preeklampsia tipe dini lebih parah dari pada tipe lambat.

Kehamilan normal terjadi perubahan fisiologis maternal untuk mengakomodasi janin, plasenta, serta produk dari unit fetoplasesenta seperti plasenta exosomes, mikropartikel dan sel-sel microchimeric. Pada kehamilan normal terjadi pergeseran keseimbangan imun Th1/Th2 ke arah respon imun tipe Th2 yang bersifat melindungi janin dari respon imun Th1 (cytotoxic) yang bisa membahayakan janin dengan produknya seperti IL-2, IL-12, Tumor Necrosis Factor (TNF)- $\alpha$ dan interferon$\gamma$. Pada preeklampsia telah terbukti memiliki kadar produk Th1 (pro-inflamasi) yang lebih tinggi dan kadar produk Th2 (anti-inflamasi) yang lebih rendah dibandingkan dengan kehamilan normal pada serum darah. Inflamasi sistemik yang muncul pada preeklampsia menyokong dominasi reaksi tipe Th1. Beberapa studi menunjukkan melimpahnya soluble marker dari aktivasi neutrofil pada preeklampsia. Studi lain menunjukkan amplifikasi inflamasi pada preeklampsia oleh aktivasi sistem komplemen. ${ }^{16,17}$ Teori inflamasi dan preeklampsia dari Redman dan Sargent membagi preeklampsia menjadi plasental dan maternal. Pada wanita normal, meskipun kehamilan normal dapat merangsang respon inflamasi sistemik, tetapi hal itu tidak cukup untuk menimbulkan pre-eklampsia. Untuk menimbulkan stimulus yang abnormal dari plasenta yang mengalami stress oksidatif. Pada wanita dengan inflamasi sistemik kronis dihubung-kan dengan kondisi semacam hipertensi kronis, diabetes, atau obesitas yang merupakan predisposisi preeklamp-sia.

Ambang batas inflamasi telah terlewati, sehingga plasenta normal dapat menstimulasi reaksi inflamasi untuk menimbulkan preeklampsia. Pada praktek klinis akan banyak terjadi gambaran campuran antara kombinasi faktor konstitusi maternal dengan iskemia plasenta. $^{6}$

Klasifikasi preeklampsia menjadi tipe dini dan lambat membawa suatu nilai prognostik yang jelas dimana tipe dini dikaitkan dengan maternal mortalitas dan perinatal morbiditas yang lebih tinggi dibandingkan tipe lambat. Preeklampsia tipe dini ditandai dengan keadaan inflamasi sistemik yang lebih tinggi dibandingkan tipe lambat. Hal ini sesuai dengan penelitian kami dimana kadar sitokin anti-inflamasi yang lebih rendah pada kelompok preeklampsia tipe dini dibandingkan tipe lambat. Keterlibatan plasenta pada preeklampsia tipe dini dimana terjadi lesi pada plasenta oleh karena hipoksia/ iskemia plasenta yang terkait dengan maternal under-fusion dapat menjelaskan hal ini. Setelah itu terjadi pelepasan dalam jumlah besar plasental material ke dalam sirkulasi maternal sehingga terjadi keadaan inflamasi yang masif dan juga dapat menyebabkan gangguan pertumbuhan janin. Pada preeklampsia tipe lambat dimana bersifat maternogenik yang umumnya terjadi pada akhir kehamilan dan tidak berhubungan dengan gangguan plasenta dan pertumbuhan janin yang terhambat.

Kondisi ini terkait dengan inflamasi kronis dengan intensitas rendah seperti IMT yang berlebih, resistensi insulin. Respon inflamasi berlebih pada preeklampsia tipe lambat juga telah dilaporkan oleh Borzychowski tahun 2006 yang mengadopsi konsep maternal preeklampsia yaitu hipertensi dan proteiunuria terjadi wanita dengan plasenta yang normal tetapi rentan terhadap inflamasi sistemik. Kehadiran inflamasi ringan selama kehamilan normal akan menambahkan keadaan inflamasi kronis dengan intensitas rendah yang sudah ada seperti obesitas, diabetes melitus. Obesitas dan penambahan berat badan selama kehamil-an merupakan beberapa faktor resiko yang dapat dimodifikasi untuk mencegah terjadinya preeklampsia. Konseling prenatal diperlukan untuk dapat menurunkan resiko terjadinya komplikasi kehamilan yang merugi-kan.

\section{SIMPULAN}

Kadar IL-10 serum yang lebih rendah pada preeklampsia berat tipe dini dibandingkan tipe lambat menunjukkan keadaan inflamasi yang lebih berat pada preeklampsia tipe dini lebih parah daripada tipe lambat.

\section{DAFTAR PUSTAKA}

1. Raghupathy R. Cytokines as Key Players in the Pathophysiology of Preeclampsia. Medical Principles and Practice. 2013;22:8-19. 
2. Matthiesen L, Berg G, Ernerudh J, Ekerfelt C, Jonsson Y, Sharma S. Immunology of preeclampsia. Chem Immunol Allergy. 2005;89:49-61.

3. Bayram M, Bostanci MS, Celtemen MB, Bagrlaclk EU, Yaman M, Civil F. Evaluation the Levels of Plasma Interleukins (IL-8, IFN- $\gamma$, IL-10) in Preeclamptic Pregnancies. Baghdad Science Journal. 2012;8(4).

4. Cunningham F, Leveno $\mathrm{K}$, Bloom S, Spong C, Dashe J, Hoffman B, et al. Williams Obstetrics. 24th ed. New York: McGraw-Hill Education; 2014

5. Thaxton JE, Sharma S. Interleukin-10: Multi-Faced Agent of Pregnancy. American Journal of Reproductive Immunology. 2010;63:482-91.

6. Redman C, Sargent I, Borzychowski AM. Inflammation and Preeclampsia. Seminars in Fetal and Neonatal Medicine. 2006;11:309-16.

7. Madazli R, Yuksel MA, Imamoglu M, et al. Comparison of Clinical and Perinatal Outcome in Early- and Late-Onset Preeclampsia. Archives of gynecology and Obstetrics. 2014:1:53-7.

8. Ornaghi S, Tyurmorezova A, Alegri $\mathrm{P}$, et al. Influencing Factors for Late-onset Preeclampsia. Journal of Maternal-Fetal and Neonatal Medicine. 2013;26(13):1299-302.

9. Dadelszen PV, Magee LA, Robert JM. Subclassification of preeclampsia. Hypertension in Pregnancy. 2003;22(2):143-8.

10. Sibai BM. Maternal and Uteroplacental Hemodynamic for the Classification and Prediction of
Preeclampsia. Journal of the American Heart Association. Hypertension. 2008;52:805-6.

11. Lamminpaa R, Julkunen KV, Gissler M, Heinonen S. Preeclampsia Complicated by Advance Maternal Age: a Registry-Based Study on Primiparous Women in Finland 1997-2008. BMC Pregnancy and Childbirth. 2012;12(47).

12. Baeten JM, Bukusi EA, Lambe M. Pregnancy Complications and Outcomes Among Overweight and Obese Nulliparous Women. American Journal of Public Health. 2001;91(3).

13. Ferrazzi E, Stampalija T, Aupont JE. The Evidence for Late-onset Preeclampsia As a Maternogenic Disease of Pregnancy. Fetal and Maternal Medicine Review. 2013;24(1):18-31

14. Kalkunte S, Nevers T, Norris WE, Sharma $S$. Vascular IL-10: A Protective Role in Preeclampsia. Journal Reproduction Immunology. 2011;88(2): 165-9.

15. Thaxton JE, Sharma S. Interleukin-10: A Multifaced Agent of Pregnancy. American Journal of Reproductive Immunology. 2010;63:482-91.

16. Bayram M, Bostanci MS, Celtemen MB, Bagrlaclk EU, Yaman M, Civil F. Inflammatory Response in Severe Preeclamptic and Preeclamptic Pregnancies. J Clin Gynecol Obstet. 2012;1(2,3):40-5.

17. Eiland E, Nzerue C, Faulkner M. Preeclampsia. Journal of Pregnancy. Hidawi Publishing Corporation. $2012 ; 12$. 